\title{
Variasi Konsentrasi Alfa Siklodekstrin dan Waktu Sentrifugasi Dalam Preparasi Serum Lipemik Pada Pemeriksaan Glukosa Metode GOD-PAP
}

\section{The Variation of Alpha Cyclodextrin and Centrifugation Time in Lipemic Serum Preparation for Glucose Examination With GOD-PAP Method}

\author{
Arfa Izzati ${ }^{1 a^{*}}$, Ani Riyani ${ }^{2 b}$ \\ 1,2 Jurusan Analis Kesehatan Poltekkes Kemenkes Bandung, Indonesia \\ a Email address: arfaarfa91@gmail.com \\ b Email address: ani_riyanianalis@yahoo.com
}

\section{HIGHLIGHTS}

- Konsentrasi alfa-siklodekstrin dan waktu sentrifugasi optimal.

\section{ARTICLE INFO}

\section{Article history}

Received date : February $09^{\text {th }}, 2018$

Revised date : March $13^{\text {rd }}, 2018$

Accepted date : March $23^{\text {rd }}, 2018$

\section{Keywords:}

Alpha Cyclodextrin Glucose GOD-PAP Lipemic Serum Centrifugation Time

\section{Kata Kunci:}

Alfa Siklodekstrin Glukosa GOD-PAP Serum Lipemik Waktu Sentrifugasi

\section{A B S T R A C T / A B S T R A K}

Examination of glucose levels of the GOD-PAP method in serum may be disrupted by the presence of turbidity caused by lipemic serum, thus causing high false serum glucose levels to result. The addition of alphacyclodextrin ( $\alpha-C D)$ may bind the lipid in serum. This study aims to find out how the concentration and time of optimal centrifugation with the addition of alpha-cyclodextrin. Added variation alpha-cyclodextrin concentration $0,5 \%, 1 \%$, and $1,5 \%$ in serum collection (pooled serum) with variation concentration of triglycerides $\pm 1000 \mathrm{mg} / \mathrm{dL}, \pm 1500 \mathrm{mg} / \mathrm{dL}$ and $\pm 2000 \mathrm{mg} / \mathrm{dL}$ with centrifugation time for 5 minutes, 10 minutes and 15 minutes at $4^{\circ} \mathrm{C}$ to form precipitate and supernatant. The supernatant measured the glucose GOD-PAP and triglycerides GPO-PAP using a photometer. The result were no significant differences in variations centrifugation time and variations alpha-cyclodextrin concentrations after comparison with serum glucose combination levels (base line) in the ANOVA test $(P=0,05)$ and Kruskall Wallis Test $(P=0,05)$. There was no significant difference with pooled serum (base line) of triglyceride concentration $\pm 1000 \mathrm{mg} / \mathrm{dL}$ with alpha-cyclodextrin concentration $0,5 \%$ and centrifugation time at 10 minute, triglyceride concentration \pm 1500 $\mathrm{mg} / \mathrm{dL}$ and $\pm 2000 \mathrm{mg} / \mathrm{dL}$ with alpha-cyclodextrin concentration $1 \%$, centrifugation time at 5 minute.

Pemeriksaan kadar glukosa metode GOD-PAP di dalam serum dapat terganggu dengan adanya kekeruhan disebabkan oleh serum lipemik yang menyebabkan hasil kadar glukosa dalam serum tinggi palsu. Penambahan alfa-siklodekstrin ( $\alpha-C D$ ) dapat mengikat lipemik di dalam serum. Penelitian ini bertujuan untuk mengetahui konsentrasi dari alfasiklodekstrin dan waktu sentrifugasi yang optimal dengan penambahan alfa-siklodekstrin. Menambahkan variasi konsentrasi alfa-siklodekstrin $0,5 \%, 1 \%$, dan $1,5 \%$ pada gabungan serum (pooled serum) dengan variasi kadar trigliserida $\pm 1000 \mathrm{mg} / \mathrm{dL}, \pm 1500 \mathrm{mg} / \mathrm{dL}$ dan $\pm 2000 \mathrm{mg} / \mathrm{dL}$ pada variasi waktu sentrifugasi selama 5 menit, 10 menit dan 15 menit. Supernatan yang terbentuk diukur kadar glukosa metode GOD-PAP dan trigliserida metode GPO-PAP menggunakan alat fotometer. Hasil yang didapatkan, tidak terdapat perbedaan pada suatu nilai secara signifikan dari variasi waktu sentrifugasi dan variasi konsentrasi alfa-siklodekstrin setelah dibandingkan dengan kadar glukosa gabungan serum awal (base line) pada uji ANOVA $(P=0,05)$. dan uji Kruskall Wallis $(P=0,05)$. Kesimpulan yang didapatkan, tidak terdapat perbedaan signifikan 
terhadap gabungan serum awal (base line) dengan kadar trigliserida \pm $1000 \mathrm{mg} / \mathrm{dL}$ dengan kadar alfa-siklodekstrin $0,5 \%$ pada waktu sentrifugasi selama 10 menit, kadar trigliserida $\pm 1500 \mathrm{mg} / \mathrm{dL}$ dan \pm 2000 $\mathrm{mg} / \mathrm{dL}$ dengan kadar alfa-siklodekstrin $1 \%$, dengan waktu sentrifugasi selama 5 menit.

Copyright (C) 2018 Jurnal Teknologi Laboratorium. All rights reserved

\section{Corresponding Author:}

\section{Arfa Izzati}

Jurusan Analis Kesehatan Poltekkes Kemenkes Bandung,

JIn. Babakan Loa No. 10 A, Bandung, Indonesia.

Email: arfaarfa91@gmail.com

\section{PENDAHULUAN}

Sekitar $70 \%$ dari semua keputusan medis didasarkan pada hasil laboratorium sehingga laboratorium memiliki peran penting dalam perawatan kesehatan. Tahap pra-analitik merupakan bagian utama yang menyumbangkan kesalahan di laboratorium. ${ }^{1}$ Hemolisis, ikterik, dan lipemik merupakan salah satu gangguan pra-analitik dan dapat mempengaruhi hasil dengan berbagai metode laboratorium. ${ }^{2,3}$ Lipemik merupakan akumulasi dari partikel lipoprotein yang berlebih di dalam darah sehingga darah menjadi keruh berwarna putih susu. Partikel terbesar dari lipoprotein yaitu kilomikron, dengan ukuran 70-1000 nm, memiliki potensi terbesar dalam menyebabkan kekeruhan sampel. ${ }^{3}$ Keberadaan sampel lipemik menyebabkan meningkatnya absorpsi cahaya sehingga mempengaruhi pemeriksaan yang menggunakan metode spektrofotometri. ${ }^{4}$ Terdapat metode dalam menilai lipemik di sampel laboratorium. Trigliserida dalam serum dapat memberikan penilaian terhadap kadar lipemik. ${ }^{5}$ Sampel lipemik dapat dimodifikasi menggunakan kuning telur ayam sehingga kuning telur ayam menjadi salah satu alternatif untuk membuat sampel lipemik buatan. ${ }^{4}$ Pemeriksaan glukosa menggunakan metode Glukosa Oxidase Para-Amino Phenazone (GOD-PAP) merupakan salah satu pemeriksaan yang dapat terganggu apabila sampel lipemik di atas $626 \mathrm{mg} / \mathrm{dL} .{ }^{6}$ Alternatif untuk menangani sampel lipemik dapat menggunakan beberapa metode yaitu; ultrasentrifugasi, pengenceran sampel, dan flokulasi lipoprotein salah satunya dengan alfa-siklodekstrin., ${ }^{3,7}$ Menurut Clinical and Laboratory Standards Institute (CLSI) pada pedoman interferensi uji telah merekomendasikan klasifikasi penanganan sampel lipemik yaitu metode ultrasentrifugasi yang merupakan standar prosedur baku. ${ }^{8}$ Namun kelemahan dari ultrasentrifugasi adalah alat yang mahal dan tidak semua laboratorium memiliki ultrasentrifuge. Metode pengenceran sampel hanya cukup untuk menghapus gangguan kekeruhan saja tanpa memastikan bahwa konsentrasi analit tetap dalam batas-batas analitis ${ }^{3}$ Siklodekstrin wujudnya berupa serbuk. merupakan kelompok oligosakarida nonpereduksi produk modifikasi pati dengan struktur kimia berbentuk cincin., ${ }^{9,10}$ Siklodekstrin memiliki permukaan luar yang bersifat hidrofilik sedangkan bagian dalam rongganya bersifat hidrofobik, dengan sifatnya tersebut, maka siklodekstrin dapat mengikat lemak di dalam serum. Toksisitas dari zat siklodekstrin alami maupun turunannya telah banyak diteliti dan terbukti atoksik. ${ }^{11}$

Penelitian yang telah dilakukan sebelumnya oleh Evan Fletcher pada tahun 2013 yaitu penambahan 2 gram alfa-siklodekstrin secara oral setelah makan dapat menurunkan kadar trigliserida tanpa mempengaruhi kadar glukosa darah setelah dibandingkan dengan placebo. ${ }^{12}$ Penelitian yang dilakukan oleh Alde Fajar Prambudi, Subrata Tri Widada dan Budi Setiawan pada tahun 2017, serum lipemik dengan flokulan gamma-siklodekstrin dengan perbandingan serum dan gamma-siklodekstrin $20 \%$ (2:1) dengan inkubasi suhu $23^{\circ} \mathrm{C}$ menggunakan kadar trigliserida $>300$ $\mathrm{mg} / \mathrm{dL}$ di sentrifugasi selama 5 menit dengan kecepatan $3000 \mathrm{rpm}$, didapatkan hasil glukosa tanpa penambahan flokulan gamma-siklodekstrin adalah $267.19 \mathrm{mg} / \mathrm{dL}$ dengan hasil glukosa penambahan flokulan gamma-siklodekstrin adalah $169.23 \mathrm{mg} / \mathrm{dL} .{ }^{13}$ Pemeriksaan glukosa menggunakan beta-siklodekstrin tidak dilakukan karena kelarutan beta-siklodekstrin dalam air tidak baik. Pemilihan flokulasi lipoprotein dengan alfa-siklodekstrin dapat menjadi salah satu alternatif untuk mengendapkan sampel lipemik. Optimalisasi waktu sentrifugasi terhadap penggunaan alfa-siklodekstrin pada sampel lipemik buatan merupakan salah satu penelitian yang belum dilakukan untuk saat ini. 
Tujuan dari penelitian ini adalah untuk menentukan konsentrasi alfa-siklodekstrin optimal yang digunakan untuk preparasi sampel lipemik dalam pemeriksaan kadar glukosa metode GODPAP dan menentukan waktu sentrifugasi optimal yang digunakan untuk preparasi sampel lipemik dalam pemeriksaan kadar glukosa metode GOD-PAP.

\section{BAHAN DAN METODE PENELITIAN}

2.1. Desain penelitian

Desain penelitian yang dilakukan adalah penelitian eksperimental.

\subsection{Lokasi penelitian}

Laboratorium Kimia Klinik, Jurusan Analis Kesehatan. Politeknik Kesehatan Kementerian Kesehatan Bandung.

2.3. Populasi dan sampel penelitian

Objek penelitian yang digunakan adalah alfa-siklodekstrin $(\alpha-C D) \geq 98 \%$ Sigma Aldrich.

\subsection{Bahan dan alat penelitian}

Alfa-siklodekstrin $\geq 98 \%$ Sigma Aldrich, gabungan serum (pooled serum), $\mathrm{NaCL}(0,9 \%$, Otsu NS), reagen glukosa GOD-PAP BIOLABO, reagen trigliserida GPO-PAP BIOLABO, fotometer Microlab 300, fotometer Kenzamax Biochemistry.

2.5. Koleksi/tahapan penelitian

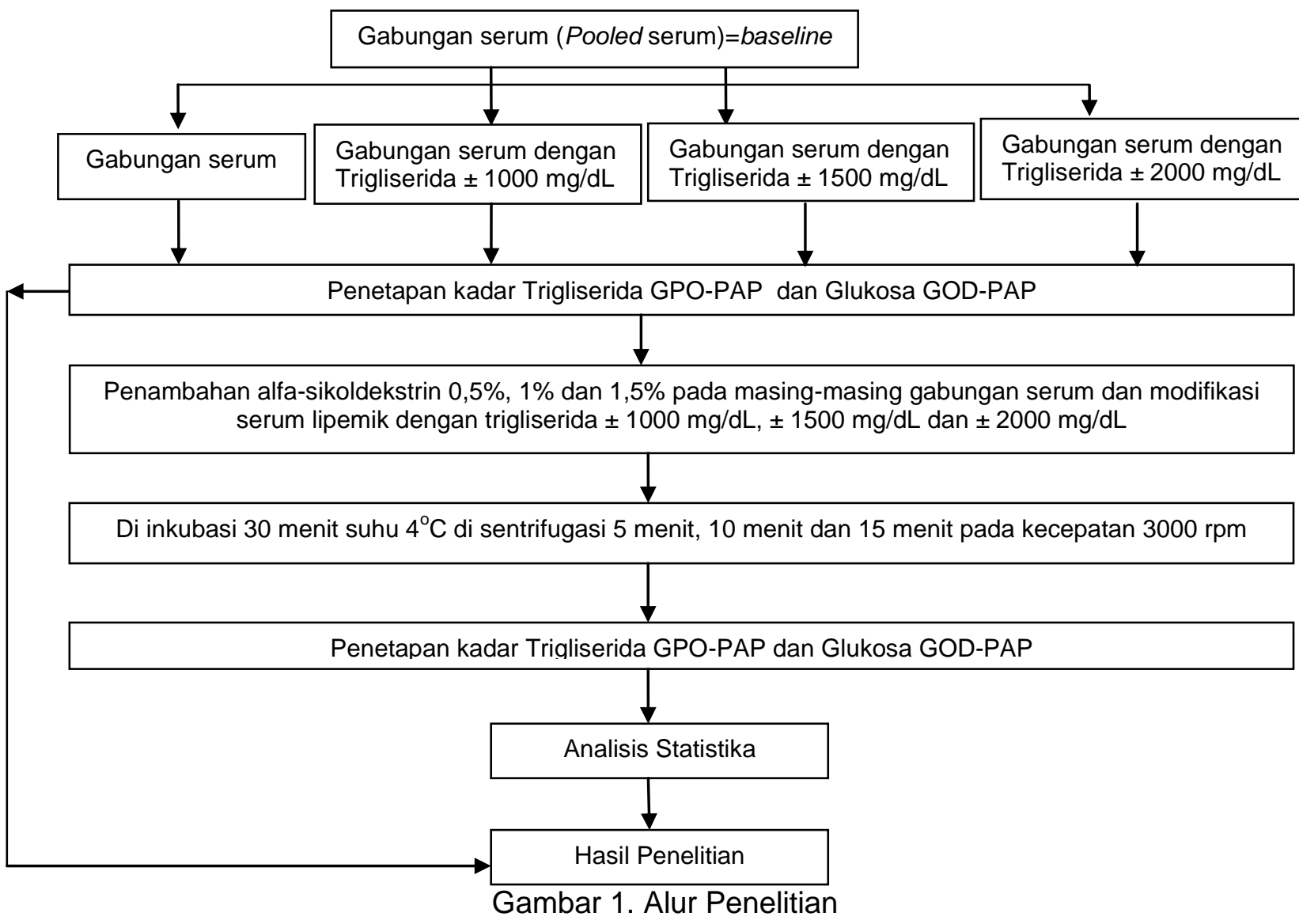

Alur Penelitian:

1. Sampel darah sebanyak $\pm 50 \mathrm{~mL}$ dikumpulkan dalam tabung yang bersih dan kering.

2. Sampel darah yang didapatkan, dilakukan preparasi untuk membuat serum.

3. Serum yang didapatkan, dilakukan penggabungan sehingga didapatkan gabungan serum (pooled serum).

4. Gabungan serum dibuat modifikasi serum lipemik buatan menggunakan kuning telur ayam dengan trigliserida $\pm 1000 \mathrm{mg} / \mathrm{dL}, \pm 1500 \mathrm{mg} / \mathrm{dL}$ dan $\pm 2000 \mathrm{mg} / \mathrm{dL}^{4}$

5. Gabungan serum dan hasil modifikasi serum lipemik buatan dilakukan pemeriksaan kadar Trigliserida GPO-PAP dan Glukosa GOD-PAP. 
6. Gabungan serum dan modifikasi serum lipemik dengan trigliserida $\pm 1000 \mathrm{mg} / \mathrm{dL}, \pm 1500 \mathrm{mg} / \mathrm{dL}$ dan $\pm 2000 \mathrm{mg} / \mathrm{dL}$ masing-masing dilakukan penambahan variasi alfa-sikoldekstrin $0,5 \%, 1 \%$ dan $1,5 \%$.

7. Gabungan serum dan modifikasi serum lipemik dengan trigliserida $\pm 1000 \mathrm{mg} / \mathrm{dL}, \pm 1500 \mathrm{mg} / \mathrm{dL}$ dan $\pm 2000 \mathrm{mg} / \mathrm{dL}$ yang masing-masing telah di preparasi, inkubasi selama 30 menit pada suhu $4^{\circ} \mathrm{C}$ dan dilakukan variasi sentrifugasi selama 5 menit, 10 menit dan 15 menit pada kecepatan $3000 \mathrm{rpm}$.

8. Gabungan serum dan hasil modifikasi serum lipemik buatan dilakukan kembali pemeriksaan kadar Trigliserida GPO-PAP dan Glukosa GOD-PAP ( $\mathrm{n}=3$ kali).

9. Analisis statistika dilakukan dari perbandingan data penetapan pemeriksaan sebelum dan setelah dipreparasi dengan variasi alfa-siklodekstrin dan variasi waktu sentrifugasi.

10. Hasil penelitian didapatkan.

2.5.1.Cara kerja modifikasi serum lipemik buatan menggunakan kuning telur ayam.

1. Kadar trigliserida yang berada di dalam kuning telur dan di dalam gabungan serum (pooled serum) diukur terlebih dahulu.

2. Nilai trigliserida diketahui, ditambahkan kuning telur dan $\mathrm{NaCl} 0,9 \%$ dengan perbandingan $1: 1$ pada serum untuk mendapatkan serum lipemik buatan dengan kadar trigliserida $\pm 1000 \mathrm{mg} / \mathrm{dL}$, $\pm 1500 \mathrm{mg} / \mathrm{dL}$ dan $\pm 2000 \mathrm{mg} / \mathrm{dL}$ digunakan rumus pengenceran.

3. Dilakukan pemeriksaan ulang kadar trigliserida untuk memastikan konsentrasi trigliserida di dalam modifikasi serum lipemik buatan.

2.5.2. Cara Kerja Pembuatan Stok Alfa-Siklodekstrin 5\%.

1. Larutan stok $5 \%$ dibuat dengan cara ditimbang terlebih dahulu serbuk alfa-siklodekstrin sebanyak 0,5 gram lalu dilarutkan pada labu ukur $10 \mathrm{~mL}$ menggunakan aquades hingga tanda batas.

2. Menggunakan rumus pengenceran, ditambahkan alfa-siklodekstrin dari larutan stok $5 \%$ sehingga didapatkan kadar sebesar $0,5 \%, 1 \%$ dan $1,5 \%$.

2.5.3. Cara Kerja Serum Lipemik dengan Penambahan Alfa-Siklodekstrin Perbandingan 2:1.[7]

1. Gabungan serum dan modifikasi serum lipemik buatan yang telah diketahui konsentrasi trigliserida $( \pm 1000 \mathrm{mg} / \mathrm{dL}, \pm 1500 \mathrm{mg} / \mathrm{dL}, \pm 2000 \mathrm{mg} / \mathrm{dL})$ dipipet $200 \mu \mathrm{L}$ ke dalam vial, dan ditambahkan $100 \mu \mathrm{L} \alpha$-siklodekstrin $0,5 \%, 1 \%$ dan $1,5 \%$ pada masing-masing vial. Inkubasi pada suhu $4^{\circ} \mathrm{C}$ selama 30 menit.

2. Sentrifugasi dilakukan dengan variasi waktu sentrifugasi selama 5 menit, 10 menit, dan 15 menit dengan kecepatan $3000 \mathrm{rpm}$ pada $4^{\circ} \mathrm{C}$ hingga didapatkan endapan dan supernatan. Supernatan yang didapat, dipisahkan untuk pemeriksaan glukosa GOD-PAP ( $\mathrm{n}=3$ kali) dan trigliserida GPOPAP lalu dikalikan dengan faktor pengenceran.

\subsection{Analisis data}

Two Way ANOVA, Kruskall Wallis dan dilanjutkan dengan Uji Mann Whitney U menggunakan aplikasi statistika. 


\section{HASIL DAN PEMBAHASAN}

Berdasarkan hasil penelitian didapatkan hasil sebagai berikut:

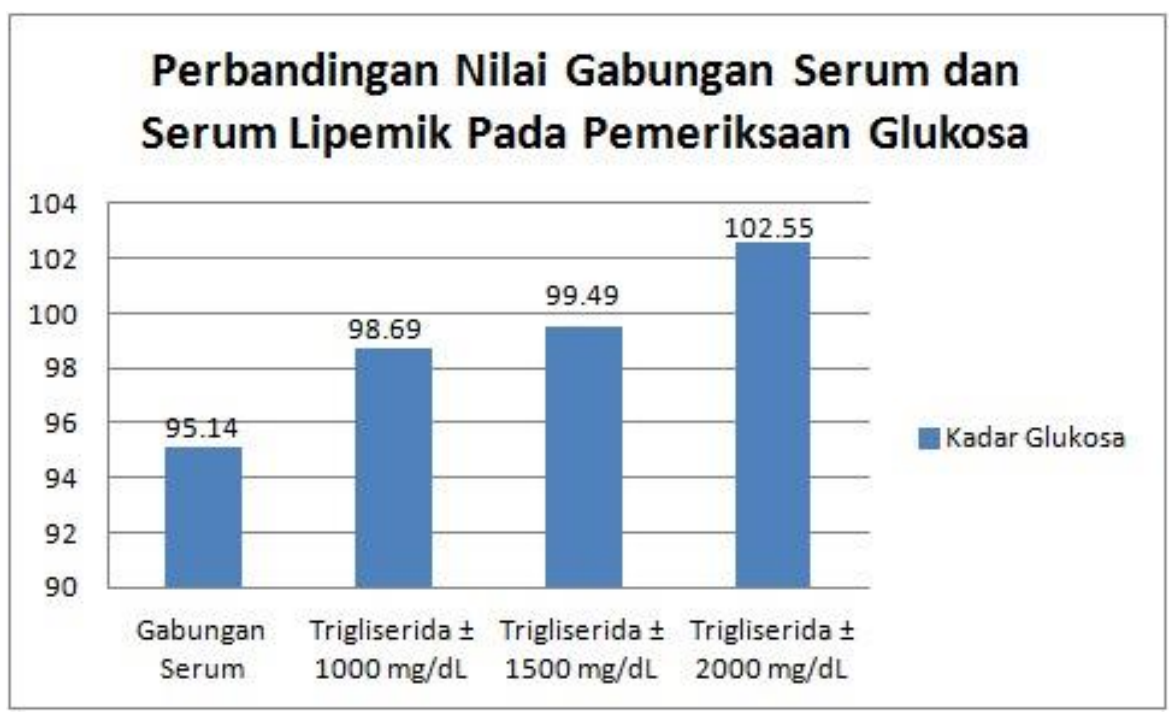

Gambar 1. Grafik Hasil Pemeriksaan Kadar Glukosa Pada Pooled Serum (Gabungan Serum) dan Lipemik Terbagi dalam Konsentrasi Trigliserida $\pm 1000 \mathrm{mg} / \mathrm{dL}, \pm 1500 \mathrm{mg} / \mathrm{dL}$ dan $\pm 2000 \mathrm{mg} / \mathrm{dL}$ Sebelum Penambahan Alfa-Siklodekstrin

Sumber: Data Primer (2017)

Kadar glukosa menjadi meningkat seiring ditambahkannya modifikasi serum lipemik buatan dengan kadar trigliserida $\pm 1000 \mathrm{mg} / \mathrm{dL}, \pm 1500 \mathrm{mg} / \mathrm{dL}$ dan $\pm 2000 \mathrm{mg} / \mathrm{dL}$. Hal ini disebabkan karena kekeruhan dalam sampel lipemik menyebabkan meningkatnya cahaya yang diabsorpsi dalam fotometer oleh partikel kekeruhan lipemik menjadikan kadar glukosa meningkat palsu (Gambar $1) .^{14}$

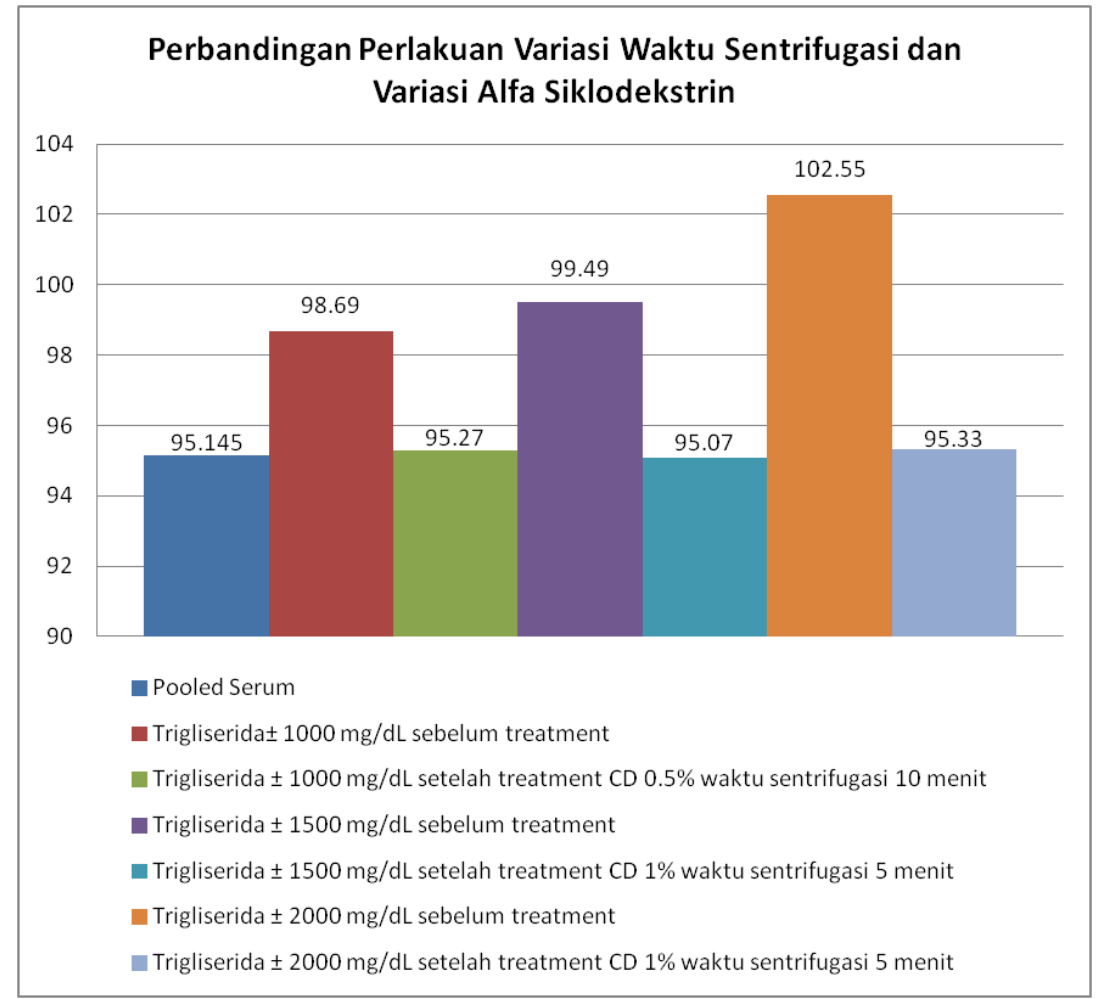

Gambar 2. Grafik Kadar Glukosa Hasil Preparasi dengan Alfa-Siklodekstrin dan Waktu Sentrifugasi

Sumber: Data Primer (2017) 
Kadar glukosa setelah dilakukan preparasi penambahan alfa-siklodekstrin pada modifikasi serum lipemik buatan dapat kembali pada keadaan awal yaitu pooled serum (base line). Konsentrasi trigliserida $\pm 1000 \mathrm{mg} / \mathrm{dL}$ optimal menggunakan alfa-siklodekstrin $0,5 \%$ dan waktu sentrifugasi 10 menit setelah dilakukan uji Kruskall Wallis $(P=0.05)$. Konsentrasi trigliserida \pm 1500 $\mathrm{mg} / \mathrm{dL}$ dan $\pm 2000 \mathrm{mg} / \mathrm{dL}$ optimal menggunakan alfa-siklodekstrin $1 \%$ dan waktu sentrifugasi 5 menit setelah dilakukan uji ANOVA ( $\mathrm{P}=0.05)$ (Gambar 2).

Kembalinya kadar glukosa modifikasi serum lipemik buatan setelah dilakukan treatment dengan alfa-siklodekstrin disebabkan oleh lipid dalam sampel lipemik dan molekul siklodekstrin yang saling mendekat lalu terjadi interaksi hidrofobik antara gugus fungsi molekul lipid dengan gugus yang terletak dalam rongga tengah siklodekstrin sehingga dapat terjadi pembentukan ikatan antara molekul lipid dan siklodekstrin. ${ }^{15}$ Setelah terjadi pengikatan, diperlukan proses sentrifugasi untuk mengendapkan lipemik yang telah berikatan dengan molekul siklodekstrin.

Hasil yang sama telah dilakukan oleh Alde Fajar Prambudi, Subrata Tri Widada dan Budi Setiawan pada tahun 2017 bahwa penggunaan gamma-siklodekstrin sebagai treatment lipemik pada pemeriksaan glukosa menunjukkan rerata selisih penurunan glukosa sebesar $97,97 \mathrm{mg} / \mathrm{dL}$, dengan nilai glukosa sebelum treatment $267,19 \mathrm{mg} / \mathrm{dL}$ dengan nilai glukosa setelah treatment 169,23 mg/dL. ${ }^{13}$ Penggunaan alfa-siklodekstrin telah dilakukan uji coba pada pemeriksaan glukosa, asam urat, aspartat aminotransferase, kalsium, urea nitrogen, bilirubin total dan alkali fosfatase. Hasil yang didapat spesimen kontrol berkorelasi baik dengan analit yang diuji. Penelitian yang dilakukan oleh Ajit Sharma pada penelitian sebelumnya bahwa analisis statistika (paired ttest) menunjukkan bahwa tidak ada perubahan yang signifikan serta menunjukkan korelasi yang baik antara metode flokulasi alfa-siklodekstrin dan ultrasentrifugasi. Sehingga penggunaan alfasiklodekstrin dapat menjadi salah satu alternatif dari ultrasentrifugasi yang merupakan standar baku untuk treatment lipemik. ${ }^{7}$

Kelemahan dari penelitian ini adalah belum dilakukan modifikasi serum lipemik buatan dengan parameter pemeriksaan yang berbeda menggunakan konsentrasi alfa-sikoldekstrin dan waktu sentrifugasi yang sama dan belum dilakukan penelitian modifikasi serum lipemik buatan dengan trigliserida $\pm 1000 \mathrm{mg} / \mathrm{dL}$ pada konsentrasi alfa-siklodekstrin dibawah $0,5 \%$ untuk penggunaan alfa-siklodekstrin yang lebih efisien.

Penelitian ini menunjukkan bahwa modifikasi serum lipemik buatan menyebabkan hasil pemeriksaan kadar glukosa tinggi palsu sehingga penggunaan metode flokulasi dengan penambahan alfa-siklodekstrin dengan variasi waktu sentrifugasi terbukti dapat digunakan untuk mengendapkan lipemik. Metode ini tidak memerlukan alat yang mahal, mudah diterapkan dan tidak berbahaya sehingga penggunakan alfa-siklodekstrin dan variasi waktu sentrifugasi dapat diaplikasikan oleh laboratorium klinis untuk menangani serum lipemik, dan hasil pemeriksaan kadar glukosa GOD-PAP menjadi akurat.

\section{SIMPULAN DAN SARAN}

Konsentrasi alfa-siklodekstrin yang optimal parameter glukosa dengan kadar trigliserida $\pm 1000 \mathrm{mg} / \mathrm{dL}$ pada alfa-siklodekstrin $0,5 \%$ dengan waktu sentrifugasi 10 menit dan kadar trigliserida $\pm 1500 \mathrm{mg} / \mathrm{dL}$ dan $\pm 2000 \mathrm{mg} / \mathrm{dL}$ pada konsentrasi alfa-siklodekstrin $1 \%$ dengan waktu sentrifugasi 5 menit.

\section{UCAPAN TERIMA KASIH}

Penulis mengucapkan terima kasih kepada Direktorat Politeknik Kesehatan Kementerian Kesehatan RI Bandung atas pembiayaan penelitian ini melalui Riset Fundamental.

\section{DAFTAR PUSTAKA}

1. Sanford Kimberly W., A. MR. "Pre-Analysis," HENRY'S Clinical Diagnosis and Management by Laboratory Methods. Elsevier Saunders. 2011;22:24-35.

2. Hoon SD, Juwon K, Young U, et al. No TitlDevelopment of an Integrated Reporting System for Verifying Hemolysis, Icterus, and Lipemia in Clinical Chemistry Results 
e. Ann Lab Med J. 2014;34(4):307.

3. Nora N. Lipemia: causes, interference mechanisms, detection and managemente. Biochem Medica J. 2014;24(1):57-67.

4. Goce D. Interference Testing. Clin Biochem Rev J. 2008;29(8):43-48.

5. Sandhya M, R DS, D KM. Frequency and causes of lipemia interference of clinical chemistry laboratory tests. Elsevier. 2017;8(2):1-9.

6. S YD. Effect of Drugs on Clinical Laboratory Tests, 1995 dalam Biolabo., "Glucose GOD-PAP," Maizy, 2011. AACC Press. 1995;4:274-294.

7. Ajit S, Karen A, W BJ. Flocculation of serum lipoproteins with cyclodextrins: Application to assay of hyperlipidemic serum. Clin Chem J. 1990;36(3):529-532.

8. Radišić BV, Sandra B, Maja K, Andrea R, M LV. Serum delipidation but not highspeed centrifugation is effective in clearing lipemia interference in serum lipase activity measurement. Clin Chem Lab Med J. 2016;54:247-249.

9. Jianxiang Z, X MP. Cyclodextrin-based supramolecular systems for drug delivery: Recent progress and future perspective,". Adv Drug Deliv Rev J. 2014;65(9):1-39.

10. Amran L. Produksi Siklodekstrin dari Substrat Tapioka dengan Menggunakan Pullulanase dan CGTase secara Simultan. J Tek Ind Pert. 2011;18(2):99-105.

11. Crestani de MJ, Azevedo MTE, Francisco V, Gomes FH. Cyclodextrins and ternary complexes: Technology to improve solubility of poorly soluble drugs. Brazilian $J$ Pharm Sci. 2011;47(4):665-681.

12. Neil FE. The Effect Of Alpha-Cyclodextrin On Acute Blood Lipid And Glycemic Responses To A Fat Containing Meal. Wayne State Univ. 2013.

13. Fajar PA, Tri WS, Budi S. Serum Lipemik Dengan Flokulan Gamma-Siklodekstrin Pada Pemeriksaan Glukosa. Med Lab Technol J. 2017;3(2):68-72.

14. Sunheimer RL, Threatte GA, Pincus MR, Lifshitz MS. Analysis: Principle of Instrumentation. In: McPherson RA, Pincus MR, eds. HENRY'S Clinical Diagnosis and Management by Laboratory Methods. 22nd ed. Philadelphia: Elsevier Saunders; 2011:47.

15. Nadya BA. Penggunaan Siklodekstrin Dalam Bidang Farmasi. Maj Farm. 2014;10(1):197-201. 